\title{
Hereditary Breast and Ovarian Cancer Screening Syndrome Profile in Women Diagnosed with Breast Cancer from Paraná State Southwest
}

\section{Perfil do rastreamento da síndrome hereditária de câncer de mama e ovário em mulheres diagnosticadas com câncer de mama na região sudoeste do Paraná}

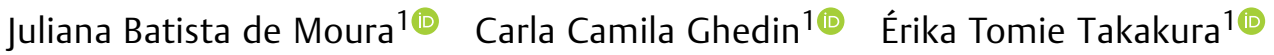 \\ Thalita Basso Scandolara1,2® Daniel Rech ${ }^{3}{ }^{\circ}$ Carolina Panis ${ }^{10}$
}

\footnotetext{
${ }^{1}$ Laboratory of Tumor Biology, Universidade do Estado do Paraná,

Francisco Beltrão, PR, Brazil

2 Department of Genetics, Universidade Federal do Rio de Janeiro, Rio de Janeiro, RJ, Brazil

${ }^{3}$ Center of Health Sciences, Francisco Beltrão Cancer Hospital,

Francisco Beltrão, PR, Brazil
}

\begin{abstract}
Address for correspondence Carolina Panis, Ph.D., Laboratory of Tumor Biology, State University of West Paraná (UNIOESTE), Rodovia Vitorio Traiano Km2, Bairro Água Branca, CEP 85601-970, Francisco Beltrão-Paraná, Brazil (e-mail: carolpanis@hotmail.com).
\end{abstract}

Rev Bras Ginecol Obstet 2021;43(8):616-621.

\begin{abstract}
Keywords

- breast cancer

- hereditary breast and ovary cancer syndrome

- cancer screening

- public health
\end{abstract}

Objective This study evaluated the risk of the hereditary breast and ovarian cancer (HBOC) syndrome in patients with breast cancer by using the Family History Screening 7 (FHS-7) tool, a validated low-cost questionnaire with high sensitivity able to screen the $\mathrm{HBOC}$ risk in the population.

Methods Women diagnosed with breast cancer $(n=101)$ assisted by the Unified Health System at the 8th Regional Health Municipal Office of the state of Paraná answered the FHS-7, and the results were analyzed using IBM SPSS Statistics for Windows, Version 25.0. software (IBM Corp., Armonk, NY, USA).

Results The risk of HBOC was $19.80 \%(n=20)$. Patients at risk exhibited aggressive tumor characteristics, such as high-grade tumors (30\%), presence of angiolymphatic emboli (35\%), and premenopausal at diagnosis (50\%). Significant associations between the prevalence of high-grade tumors were observed in women younger than 50 years at diagnosis with $\mathrm{HBOC}(p=0.003)$.

Conclusion Our findings suggest a possible family inheritance associated with worse clinical features in women with breast cancer in this population, indicating that $\mathrm{HBOC}$ investigation can be initially performed with low-cost instruments such as FHS-7. received

July 7,2020

accepted

May 27, 2021
DOI https://doi.org/

10.1055/s-0041-1733998. ISSN 0100-7203.
(C) 2021. Federação Brasileira de Ginecologia e Obstetrícia. All rights reserved.

This is an open access article published by Thieme under the terms of the Creative Commons Attribution License, permitting unrestricted use, distribution, and reproduction so long as the original work is properly cited. (https://creativecommons.org/licenses/by/4.0/)

Thieme Revinter Publicações Ltda., Rua do Matoso 170, Rio de Janeiro, RJ, CEP 20270-135, Brazil 


\section{Resumo}

Palavras-chave

- câncer de mama

- síndrome hereditária de câncer de mama e ovário

- rastreamento de câncer

- saúde pública
Objetivo Este estudo avaliou o risco da síndrome hereditária de câncer de mama e ovário (HBOC, na sigla em inglês) em pacientes com câncer de mama utilizando a ferramenta Familial History Screening 7 (FHS-7), um questionário validado de baixo custo e com alta sensibilidade capaz de rastrear o risco de HBOC na população.

Métodos Mulheres diagnosticadas com câncer de mama $(n=101)$ assistidas pelo Sistema Único de Saúde da 8a Regional de Saúde do estado do Paraná responderam ao questionário FHS-7, e os resultados foram analisados pelo software IBM SPSS for Windows, Version 25.0. (IBM Corp., Armonk, NY, EUA).

Resultados A ocorrência do risco de HBOC foi de 19,80\% $(n=20)$. Pacientes em risco exibiram características agressivas do tumor como tumores de alto grau (30\%), presença de êmbolos angiolinfáticos (35\%) e pré-menopausa ao diagnóstico (50\%). Associações significantes foram observadas entre a prevalência de tumores de alto grau e diagnóstico abaixo de 50 anos no grupo HBOC $(p=0.003)$.

Conclusão Nossos achados sugerem uma possível herança familiar associada a piores características clínicas em mulheres com câncer de mama nessa população, indicando que a investigação de $\mathrm{HBOC}$ pode ser realizada, inicialmente, com instrumentos de baixo custo, como o FHS-7.

\section{Introduction}

Breast cancer is the major cause of women's death in the world. In Brazil, 60,000 new cases are estimated for 2020. ${ }^{1}$ Around 5 to $10 \%$ of breast cancer cases occur due to inheritance of mutated genes in the DNA repair pathway, such as BRCA1, BRCA2, and TP53. ${ }^{2}$ These mutations increase the probability of cancer in the breast, ovaries, ovarian tubes, peritoneum, prostate, intestine, and colon, among other neoplasms not well established in the literature yet. ${ }^{3}$ Despite the high prevalence of breast cancer in the Brazilian population, there is a lack of studies conducted in patients with germline mutations and familial cancer. In addition, the southern region of Brazil presents the highest incidence of hereditary breast cancer, which usually results in tumors with poor prognosis and increased rates of death, social, and health costs, such as triple-negative tumors. ${ }^{4,5}$

Age at diagnosis under 50 years old, pre-menopausal status, and being overweight at the time of diagnosis represent independent risk factors for the disease. ${ }^{6}$ In comparison to luminal subtypes, that have estrogen and/or progesterone receptors, triple-negative (negative for all receptors) and human epidermal growth factor receptor 2 -positive (HER-2) breast cancers usually present high proliferation rates and are considered more aggressive tumors. ${ }^{5}$ High histological grade, lymph node involvement, and presence of angiolymphatic emboli are also prognostic factors. ${ }^{7}$ Young women (under 35 years old) with inherited breast cancer usually presents, worse disease characteristics, such as triple-negative tumors, which have few therapeutic options and low survival rates. ${ }^{8,9}$

However, genetic testing for $\mathrm{HBOC}$ is not affordable for many patients, and the implementation of cancer counselling and testing in the public health system represents a challenge due to its high cost. A simple, low-cost, sensitive, and easily applicable instrument in primary care units would be partic- ularly useful in underserved communities, where the identification and referral of high-risk individuals is difficult.

In this context, a Brazilian study conducted by AshtonProlla et al. ${ }^{10}$ proposed the use of a screening instrument to assess the family history of breast cancer in individuals with an increased risk for hereditary syndromes, the Family History Screening 7 (FHS-7) questionnaire. This tool is composed by seven simple questions that are suggestive of HBOC, based on familial and patient cancer history. The instrument was validated for the Brazilian population attended in primary care unities, and consists in an adequate screening approach to identify at-risk individuals that could get benefit from genetic tests in the future.

As far as we know, the FHS-7 instrument has never been applied in the population of Southern Paraná. Thus, the present study aims to use the FHS-7 tool to screen breast cancer patients treated in a public oncology reference center to outline the syndrome profile in this population and investigate any clinicopathological correlation.

\section{Methods}

This is an observational, descriptive, and prospective transversal study, approved by the ethics committee of the Universidade do Estado do Paraná (CAAE 35524814.4.0000.0107). Patients $(n=350)$ attended in a public oncology hospital located in Francisco Beltrão, Paraná, which is the reference for 27 municipalities in the Southwest of Paraná under the 8th Regional Health Municipal Office of the State of Paraná and the Unified Health System, from January 2016 to August 2018. The patients were selected during routine doctor appointments, after analysis of image exams and/or biopsy results.

Eligible patients were women diagnosed with breast invasive ductal carcinoma (IDC) who volunteered and signed 
Chart 1 Family History Screening 7 (FHS-7) questionnaire ${ }^{10}$

\section{Questions}

1. Do you, or any first-degree relative, have or have had breast cancer?

2. Do you or any first-degree relative have or had bilateral breast cancer?

3. Has any man in your family had breast cancer?

4. Did any woman in your family have breast and ovarian cancer?

5. Has any woman in your family had breast cancer before the age of 50 ?

6. Do you have two or more relatives with breast and / or ovarian cancer?

7. Do you have two or more relatives with breast and / or bowel cancer?

a consent form ( $n=101)$, and the inclusion criteria consisted in patients that were able to fully answer the questions, dichotomized as yes or no, in the FHS-7 questionnaire (Chart 1), validated for the Brazilian population to evaluate individuals at $\mathrm{HBOC}$ risk. ${ }^{10}$

Patients who responded positively to at least one of the questions were considered possible carriers of the syndrome. Based on the stratification of patients by the FHS-7 questionnaire, two groups were defined: the first was called HBOC-risk and was composed of those who answered positively to at least one of the questions in the questionnaire; and the second group was called sporadic cancer and was composed of patients who answered negatively to all questions.

The following parameters were collected from the patients' medical records: histological type of tumor (World Health Organization [WHO] classification); ${ }^{11}$ estrogen, progesterone, and HER2 receptors status; molecular subtype (St. Gallen Consent); ${ }^{12}$ tumor size; tumor grade (Nottingham prognostic index); ${ }^{13}$ involvement of the surgical margins; presence of angiolymphatic emboli; age at diagnosis; body mass index (BMI), and menopausal status.

The variables were analyzed for statistical assumptions of normality (Shapiro-Wilk test) and homoscedasticity (Levene test). The results were assessed with the Grubbs test for the detection of outliers, and no outliers were detected. The frequency of the variables was determined as percentages, and the Person Chi-square and linear logistic regression tests were used to verify putative associations between the frequencies of the categorical variables ( $\beta$ and $p$-values were reported). For these analyses, the software IBM Statistical Package for the Social Science for Windows version 25.0 (IBM Corp., Armonk, NY, USA) was used. The statistical significance adopted for the analyses was $5 \%$. Only the significant associations were reported in the study.

\section{Results}

Among the patients, $80.2 \%$ answered negatively to all questions of the FHS-7 questionnaire, gathered in the "sporadic cancer" group $(n=81)$. The remaining patients $(n=20)$, the HBOC-risk group, answered positively to at least one of the instrument questions, which results in a prevalence of $19.8 \%$ for $\mathrm{HBOC}$ risk in the studied population. All patients included were Caucasian, agreeing with the characteristics of European colonization in the region studied.

The differences between the groups were not significant, and are only qualitatively described. There is a prevalence of negative hormone receptors (estrogen or progesterone) in the sporadic cancer group ( $46 \%$ and $52 \%$, respectively), when compared with the HBOC-risk group (35\% and 45\%, respectively). Regarding the overexpression of HER2 receptors,

Table 1 Clinicopathological characterization of the cohort

\begin{tabular}{|c|c|c|c|}
\hline Parameters & $\begin{array}{l}\text { Sporadic } \\
\text { cancer }\end{array}$ & HBOC-risk & $\begin{array}{l}\text { Chi-squared } \\
\text { test }\end{array}$ \\
\hline \multicolumn{4}{|l|}{$\begin{array}{l}\text { Molecular receptors } \\
\text { status }\end{array}$} \\
\hline $\begin{array}{l}\text { Absence of estrogen } \\
\text { receptors }\end{array}$ & $46 \%(n=37)$ & $35 \%(n=7)$ & \\
\hline $\begin{array}{l}\text { Absence of } \\
\text { progesterone receptors }\end{array}$ & $52 \%(n=42)$ & $45 \%(n=9)$ & $P>0.05$ \\
\hline $\begin{array}{l}\text { Absence of HER2 } \\
\text { receptors }\end{array}$ & $12 \%(n=10)$ & $20 \%(n=4)$ & \\
\hline $\begin{array}{l}\text { Molecular subtypes } \\
\text { Luminal A }\end{array}$ & $36 \%(n=29)$ & $45 \%(n=9)$ & $P>0.05$ \\
\hline Luminal B & $33 \%(n=27)$ & $25 \%(n=5)$ & \\
\hline Luminal-HER2/HER2 & $12 \%(n=10)$ & $10 \%(n=2)$ & \\
\hline Triple-negative & $19 \%(n=15)$ & $20 \%(n=4)$ & \\
\hline Histological tumor grade & & & $P>0.05$ \\
\hline Low & $40 \%(n=32)$ & $45 \%(n=9)$ & \\
\hline Intermediate & $42 \%(n=34)$ & $25 \%(n=5)$ & \\
\hline High & $18 \%(n=15)$ & $30 \%(n=6)$ & \\
\hline Angiolymphatic emboli & & & $P>0.05$ \\
\hline Presence & $33 \%(n=27)$ & $35 \%(n=7)$ & \\
\hline Absence & $67 \%(n=54)$ & $65 \%(n=13)$ & \\
\hline Age at diagnosis & & & $P>0.05$ \\
\hline Under 50 years & $40 \%(n=32)$ & $35 \%(n=7)$ & \\
\hline Above 50 years & $60 \%(n=49)$ & $65 \%(n=13)$ & \\
\hline $\begin{array}{l}\text { Body mass index } \\
\left(\mathrm{BMl}, \mathrm{kg} / \mathrm{m}^{2}\right)\end{array}$ & & & $P>0.05$ \\
\hline Eutrophic & $36 \%(n=29)$ & $50 \%(n=10)$ & \\
\hline Overweight & $40 \%(n=32)$ & $25 \%(n=5)$ & \\
\hline Obese & $24 \%(n=19)$ & $25 \%(n=5)$ & \\
\hline $\begin{array}{l}\text { Menopause Status at } \\
\text { diagnosis }\end{array}$ & & & $P>0.05$ \\
\hline Yes & $52 \%(n=42)$ & $50 \%(n=10)$ & \\
\hline No & $48 \%(n=39)$ & $50 \%(n=10)$ & \\
\hline Lymphnodal involvement & & & $P>0.05$ \\
\hline Yes & $24 \%(n=19)$ & $25 \%(n=5)$ & \\
\hline No & $76 \%(n=62)$ & $75 \%(n=15)$ & \\
\hline
\end{tabular}

Abbreviations: BMI, body mass index; HBOC, hereditary breast and ovarian cancer syndrome; HER2, human epidermal growth factor receptor-type2. 
Table 2 Significant associations found in the HBOC-risk and sporadic cancer groups

\begin{tabular}{|c|c|c|}
\hline HBOC-risk & Beta value & $p$-value \\
\hline $\begin{array}{l}\text { Molecular subtype } x \text { histological } \\
\text { grade }\end{array}$ & 0.600 & 0.005 \\
\hline Age $x$ histological grade & 0.621 & 0.003 \\
\hline $\begin{array}{l}\text { Angiolymphatic invasion x } \\
\text { lymphnodal metastasis }\end{array}$ & 0.545 & 0.013 \\
\hline $\begin{array}{l}\text { Menopause at diagnosis } \mathrm{x} \\
\text { lymphnodal metastasis }\end{array}$ & 0.577 & 0.008 \\
\hline Sporadic cancer & Beta value & $\overline{p \text {-value }}$ \\
\hline $\begin{array}{l}\text { Molecular subtype } x \text { histological } \\
\text { grade }\end{array}$ & 0.225 & 0.045 \\
\hline $\begin{array}{l}\text { Angiolymphatic invasion } \mathrm{x} \\
\text { lymphnodal metastasis }\end{array}$ & 0.474 & 0.000 \\
\hline
\end{tabular}

Abbreviation: HBOC, hereditary breast and ovarian cancer syndrome.

there was a predominance in the HBOC-risk group in comparison to the sporadic cancer group (20\% versus $12 \%$, respectively). The clinicopathological characterization of patients is recorded in - Table 1.

Both groups showed a similar distribution regarding molecular subtypes, age at diagnosis, menopause status and BMI classification as overweight/obese. The HBOC-risk group presented high-grade tumors more frequently than the sporadic cancer group (30\% vs $18 \%$, respectively), as well as intratumoral angiolymphatic emboli (35\% vs 33\% from the sporadic group) and lymph node involvement (25\% vs $23 \%$ from the sporadic cancer group).

Regarding the HBOC-risk group, we found significant association between high histological grade and the occurrence of triple-negative tumors and high histological grade at diagnosis with age at diagnosis (under 50 years). Lymph node involvement was found to be significantly associated with the presence of angiolymphatic emboli in patients as well as being menopausal at diagnosis. The associations observed in the sporadic cancer group show a direct relationship between subtype and histological grade and between angiolymphatic emboli and lymph node involvement. The beta and p-values of $\beta$ are described in - Table 2 .

\section{Discussion}

As far as we know, this is the first Brazilian study to apply the FHS-7 tool for screening the risk of HBOC in women with breast cancer in the Southwest region of Paraná, where most of its population is composed by European ancestry and inbreeding due to the geographic peculiarities of rugged relief. The prevalence of mutations in the BRCA1/2 genes is associated with the occurrence of triple negative breast tumors and are higher in Caucasians when compared with Hispanics. ${ }^{14}$ Furthermore, inbreeding has been identified as one of the possible causes for HBOC-associated mutations in BRCA1/2. ${ }^{15}$ Thus, the studied population presents a favorable scenario for the occurrence of the HBOC syndrome.
The FHS-7instrument has high sensitivity for large-scale HBOC risk screening when compared with other molecular biology tools. ${ }^{10}$ Thus, the analysis found that 16 patients (15.84\%) have familial breast cancer diagnosed at early age, $5 \%$ have a first-degree family member with bilateral disease $(n=5)$. No involvement was found concerning male relatives.

Regarding hormone receptors, patients in the HBOC-risk group had positive estrogen and progesterone receptors in only $35 \%$ and $45 \%$ of the cases, respectively, which may impair the response capacity to anti-hormone therapy and could impact the prognosis. In contrast, the sporadic cancer group showed an index of $46 \%$ for estrogen and $52 \%$ for progesterone. The normal functioning of the BRCA1 gene protects breast tissue from genomic instability induced by estrogen, which could be associated with the better prognosis observed in tumors with positive hormonal receptors. ${ }^{14}$

Increased high-grade tumors were found in the HBOC-risk group (45\%), representing an important factor of worse prognosis and lower survival. ${ }^{16}$ A similar result was found by Amendola \& Vieira, according to whom patients with hereditary breast neoplasms had increased prevalence of high-grade disease, frequently related to negative estrogen and progesterone receptors. ${ }^{17}$

In addition, the presence of intratumoral angiolymphatic emboli may predict the likelihood of lymph node invasion and could be a poor prognostic finding. ${ }^{18}$ In our study, 35\% patients of HBOC-risk group presented of angiolymphatic emboli, and $25 \%$ presented lymph node involvement. As for the body mass index (BMI), overweight and obesity are risk factors for development of postmenopausal breast cancer and may represent an additional risk for BRCA1 and BRCA2 mutation carriers, which are strongly associated with HBOC. $^{19-22}$ We found that $50 \%$ of the HBOC-risk group were classified as overweight (25\%) or obese $(25 \%)$.

Regarding age at diagnosis, older women had high-grade tumors. However, aging leads to the accumulation of free radicals, molecules capable of maintaining genomic instability that promotes cellular undifferentiating in breast tumors. ${ }^{23}$ That is, both young and older patients have factors that contribute for the development of undifferentiated tumors. ${ }^{24}$ In addition, the occurrence of high-grade tumors is also increased in BRCA-mutation carriers due to impaired DNA repair against lesions promoted by free radicals. ${ }^{25}$

It is argued that even in the presence of lymph node involvement or tumors with aggressive subtypes, postmenopausal patients have a better prognosis when compared with those diagnosed younger than 35 years old. ${ }^{24}$ The perspective of heredity among the patients in our study (19.8\%), according to FHS-7, exceeds the average described by other national studies, such as the survey conducted by Dufloth et al., ${ }^{26}$ which included Brazilian and Portuguese patients, and found a prevalence of familial breast cancer of $13 \%$.

Exclusive associations were found in the HBOC group. Positive significant associations were identified concerning age at diagnosis and histological grade, indicating that older patients from the HBOC group have more undifferentiated tumors. The expression of BRCA1 is associated with familial 
breast tumors history; ${ }^{14,15}$ its high expression has been reported in high grade cancers ${ }^{27}$ and is believed to be a negative factor for patient survival. ${ }^{28}$ However, no studies were found about the role of age in this context. Another significant relationship identified was the positive correlation between menopausal status at diagnosis and lymphnodal invasion in HBOC patients, suggesting that, in this group, the active hormonal status directly affects tumor invasiveness. These findings reinforce that the reproductive hormones have some additional impact that affects breast cancer aggressiveness in women at HBOC risk.

The limitations of the study include the small sample size, which precluded a more refined statistical design and the assessment of relevant outcomes, such as survival and relative risk. A strength of the study is that this kind of data are scarce in literature and add knowledge since they bring new information about the clinicopathological characteristics of women with breast cancer at HBOC risk in a geographical area where this syndrome seems to have a high prevalence.

\section{Conclusion}

The present study used an investigation tool to evaluate the prevalence of HBOC risk in patients from the Southwest region of Paraná, whose prevalence exceeded the one found by other published studies in similar populations. Besides, patients at risk were associated with clinicopathological factors related with aggressive disease. The study indicates that the FHS-7 questionnaire could be used for the identification of patients at high risk for HBOC syndrome, enabling early detection and effective cancer prevention as well as genetic counselling.

\section{Contributors}

C. P. and D. R. conceived and planned the study. The other authors performed the interviews and interpretation of the results. All authors wrote the manuscript and provided critical feedback.

\section{Conflict of Interests}

There is no conflict of interests to declare.

\section{Acknowledgments \\ Programa de Pesquisa Para o SUS-PPSUS Chamada Pública 01/2016, Coordenação de Aperfeiçoamento de Pessoal de Nível Superior (CAPES-1 master's scholarship), Programa de Bolsas de Produtividade em Pesquisa e Desenvolvi- mento Tecnológico (1 scientific productivity scholarship), Fundação Araucária (Edital Nº 026/2016 e 3 scientific initiation scholarship).}

\section{References}

1 Ministério da Saúde. Instituto Nacional de Câncer José Alencar Gomes da Silva. Estimativa 2020: incidência de câncer no Brasil. Rio de Janeiro: INCA; 2019
2 Nielsen FC, van Overeem Hansen T, Sørensen CS. Hereditary breast and ovarian cancer: new genes in confined pathways. Nat Rev Cancer. 2016;16(09):599-612. Doi: 10.1038/nrc.2016.72

3 Eleje GU, Eke AC, Ezebialu IU, Ikechebelu JI, Ugwu EO, Okonkwo OO. Risk-reducing bilateral salpingo-oophorectomy in women with BRCA1 or BRCA2 mutations. Cochrane Database Syst Rev. 2018;8(08):CD012464. Doi: 10.1002/14651858.CD01 2464.pub2

4 Palmero EI. Identificação e caracterização de pacientes em risco para câncer de mama hereditário no sul do Brasil [tese]. Porto Alegre: Universidade Federal do Rio Grande do Sul; 2007

5 Arpino G, Milano M, De Placido S. Features of aggressive breast cancer. Breast. 2015;24(05):594-600. Doi: 10.1016/j.breast.2015.06.001

6 Schneider IJ, d'Orsi E. Sobrevida em cinco anos e fatores prognósticos em mulheres com câncer de mama em Santa Catarina, Brasil. Cad Saude Publica. 2009;25(06):1285-1296. Doi: 10.1590/ S0102-311X2009000600011

7 Curtit E, Mansi L, Maisonnette-Escot Y, Sautière JL, Pivot X. Prognostic and predictive indicators in early-stage breast cancer and the role of genomic profiling: Focus on the Oncotype DX ${ }^{\circledR}$ Breast Recurrence Score Assay. Eur J Surg Oncol. 2017;43(05): 921-930. Doi: 10.1016/j.ejso.2016.11.016

8 Reis-Filho JS, Tutt AN. Triple negative tumours: a critical review. Histopathology. 2008;52(01):108-118. Doi: 10.1111/j.13652559.2007.02889.x

9 Wang YA, Jian JW, Hung CF, et al. Germline breast cancer susceptibility gene mutations and breast cancer outcomes. BMC Cancer. 2018;18(01):315. Doi: 10.1186/s12885-018-4229-5

10 Ashton-Prolla P, Giacomazzi J, Schmidt AV, et al. Development and validation of a simple questionnaire for the identification of hereditary breast cancer in primary care. BMC Cancer. 2009; 9:283. Doi: 10.1186/1471-2407-9-283

11 Sinn HP, Kreipe H. A brief overview of the WHO Classification of Breast Tumors, 4th edition, focusing on issues and updates from the 3rd edition. Breast Care (Basel). 2013;8(02):149-154. Doi: $10.1159 / 000350774$

12 Goldhirsch A, Winer EP, Coates AS, et al; Panel members. Personalizing the treatment of women with early breast cancer: highlights of the St Gallen International Expert Consensus on the Primary Therapy of Early Breast Cancer 2013. Ann Oncol. 2013;24 (09):2206-2223. Doi: 10.1093/annonc/mdt303

13 Galea MH, Blamey RW, Elston CE, Ellis IO. The Nottingham Prognostic Index in primary breast cancer. Breast Cancer Res Treat. 1992;22(03):207-219. Doi: 10.1007/BF01840834

14 Greenup R, Buchanan A, Lorizio W, et al. Prevalence of BRCA mutations among women with triple-negative breast cancer (TNBC) in a genetic counseling cohort. Ann Surg Oncol. 2013;20 (10):3254-3258. Doi: 10.1245/s10434-013-3205-1

15 Loizzi V, Cicinelli E, Santamaria F, et al. BRCAmut and "founder effect": a prospective study in a single academic institution. Oncotarget. 2018;9(32):22353-22358. Doi: 10.18632/oncotarget.24959

16 Rakha EA, Reis-Filho JS, Baehner F, et al. Breast cancer prognostic classification in the molecular era: the role of histological grade. Breast Cancer Res. 2010;12(04):207. Doi: 10.1186/bcr2607

17 Amendola LC, Vieira R. A contribuição dos genes BRCA na predisposição hereditária ao câncer de mama. Rev Bras Cancerol. 2005; 51(04):325-330

18 Song YJ, Shin SH, Cho JS, Park MH, Yoon JH, Jegal YJ. The role of lymphovascular invasion as a prognostic factor in patients with lymph node-positive operable invasive breast cancer. J Breast Cancer. 2011;14(03):198-203. Doi: 10.4048/jbc.2011.14.3.198

19 Calle EE, Kaaks R. Overweight, obesity and cancer: epidemiological evidence and proposed mechanisms. Nat Rev Cancer. 2004;4 (08):579-591. Doi: 10.1038/nrc1408

$20 \mathrm{Kim} \mathrm{JY}$, Lee DW, Lee KH, et al. Prognostic role of body mass index is different according to menopausal status and tumor subtype in 
breast cancer patients. Breast Cancer Res Treat. 2019;176(02): 453-460. Doi: 10.1007/s10549-019-05249-1

21 Inumaru LE, Silveira EA, Naves MM. [Risk and protective factors for breast cancer: a systematic review]. Cad Saude Publica. 2011; 27(07):1259-1270. Doi: 10.1590/s0102-311X2011000700002 Portuguese

22 Guinan EM, Hussey J, McGarrigle SA, et al. A prospective investigation of predictive and modifiable risk factors for breast cancer in unaffected BRCA1 and BRCA2 gene carriers. BMC Cancer. 2013; 13:138. Doi: 10.1186/1471-2407-13-138

23 Benz CC, Yau C. Ageing, oxidative stress and cancer: paradigms in parallax. Nat Rev Cancer. 2008;8(11):875-879. Doi: 10.1038/nrc2522

24 Freedman RA, Partridge AH. Management of breast cancer in very young women. Breast. 2013;22(Suppl 2):S176-S179. Doi: 10.1016/j.breast.2013.07.034
25 Fridlich R, Annamalai D, Roy R, Bernheim G, Powell SN. BRCA1 and BRCA2 protect against oxidative DNA damage converted into double-strand breaks during DNA replication. DNA Repair (Amst). 2015;30:11-20. Doi: 10.1016/j.dnarep.2015.03.002

26 Dufloth RM, Carvalho S, Heinrich JK, et al. Analysis of BRCA1 and BRCA2 mutations in Brazilian breast cancer patients with positive family history. Sao Paulo Med J. 2005;123(04):192-197. Doi: 10.1590/s1516-31802005000400007

27 Hussein IA, Ahmed ST, Hameedi AD, et al. Immunohistochemical expression of BRCA1 protein, ER, PR and Her2/neu in breast cancer: a clinicopathological study. Asian Pac J Cancer Prev. 2020;21(04):1025-1029. Doi: 10.31557/APJCP.2020.21.4.1025

28 Huszno J, Kołosza Z, Grzybowska E. BRCA1 mutation in breast cancer patients: Analysis of prognostic factors and survival. Oncol Lett. 2019;17(02):1986-1995. Doi: 10.3892/ol.2018.9770 